практической конференции 31 января 2017 г. - Ч. 4. - С. 31 - 35. - Самара: Изд-во НИЦ «ЛЖурнал», 2017 - 36 с.

4. Селюкова И. На пути к триллиону: Как белгородские аграрии планируют накормить страну / Ирина Селюкова // Белгородские известия. - 2016. - 24 сент. - С. 2.

5. Шедий, Е.Г. Агропромышленные холдинги Белгородской области. Практика формирования и эффективность функционирования наиболее крупных агрохолдингов (на примере Белгородской области) [Электронный ресурс] / Е. Г. Шедий // Российское предпринимательство. - 2011. - С. $177-$ 180. - №1(2) (Экономика и экономические науки). - Научная электронная библиотека "КиберЛенинка". - 2011-2017. - Режим доступа: https:/cyberleninka.ru/article/n/agropromyshlennyeh... - 14.06.2017.

6. Ращенко А.В., Перькова М.В. Проблема развития общественных пространств в малых городах. Вестник БГТУ им. В.Г. Шухова. - 2015. - №1. - С.61-64.

7. Историческая справка [Электронный ресурс] : Официальный сайт органов местного самоуправления муниципального района "Корочанский район" Белгородской области. - 20092013.- Режим доступа: http://www.korocha.ru/istoricheskaya_spravka. - 13.06.2017.

8. Козлова Н. На корочанском консервном заводе будут выпускать тыквенный сок [Электронный ресурс] / Наталия Козлова // Белпресса. - 2016. - 10 июня. - Режим доступа: https://www.belpressa.ru/news/news/na-korochanskom-konservnom-zavode-budut-vypuskat-. tykvennyjsok13501/. - 13.06.2017.

9. История предприятия [Электронный ресурс] : офиц. сайт ООО «Пивоваренная компания «Старая крепость». - 2015. - Режим доступа: http://www.starayakrepost31.ru/o-nas/istoriya-predpriyatiya/. 16.06.2017.

10. Перькова М.В. Формирование линейно-узловой структуры расселения. Вестник БГТУ им. В.Г. Шухова. - 2017. - №2. - С.120-125.

11. Перькова М.В., Ладик Е.И. Формирование структуры туристско-рекреационных территорий Белгородской области с учетом региональных особенностей. Архитектура и строительство России. - 2017. - № 1 (221). - С. 85-92.

\title{
Пешкова Д.А. \\ Выявление проблем типологического разнообразия городского жилья для людей пенсионного возраста
}

СамГТУ

(Россия, Самара)

doi: $10.18411 / s p c-28-10-2017-04$

idsp: 000001:spc-28-10-2017-04

\section{Аннотация}

В статье рассмотрены проблемы старения населения, демографическая ситуация в России нехватки жилья для престарелых. Рассмотрены варианты проблем решения расселения людей «третьего возраста»

Ключевые слова: пожилые люди, дома престарелых.

\section{Abstract}

The article considers the problems of population aging, the demographic situation in Russia, the shortage of housing for the elderly. The variants of the problems of solving the settlement of people of the "third age"

Key words: elderly people, nursing homes.

С 1960-х годов, в странах западной Европы, США и Австралии был повышенный интерес и устойчивый рост строительства зданий, для пожилых людей, в том числе жилья для престарелых, центров круглосуточного ухода и опеки за пенсионерами. 
На сегодняшний день проблема старения актуальна и стала ощутимо влиять на социальную сферу всей Восточной Европы, в том числе и России. В процессе демографического смещения среднего возраста и отток работоспособного населения в крупные города, обусловили сообщества низкой плотности с преобладающими по численности населением пенсионного возраста. Если управление регионов и предпринимает попытки материальной поддержки и медицинской помощи пожилым людям, то социальная сторона вопроса оказалась не разрешенной.

Несмотря на то, что программно-целевые инструменты действий в интересах пожилых людей в Российской Федерации стали использоваться со второй половины 90х гг., нельзя сказать, что они были основаны на комплексном подходе к этой проблеме. К сожалению, типология жилья для пожилых людей практически не исследовалась и не развивалась со времени распада СССР.

Увеличение доли пожилых людей в общей численности населения, считается одной из самых острых проблем человечества.Учёт тенденций и последствий демографического старения является важнейшей задачей демографической политики и должен быть увязан со стратегией формирования жилищной политики на государственном уровне.

Согласно статистики Росстата[1] в России с каждым годом количество пожилых людей увеличивается, но проблема расселения их никак не решается, когда в других странах, как Сингапур или Китай, активно занимаются возведением зданий для разных демографических групп населения.

В ходе исследования были изучены следующие примеры решений расселения пожилых людей:

Homefarm [2] находится в Сингапуре. Проект
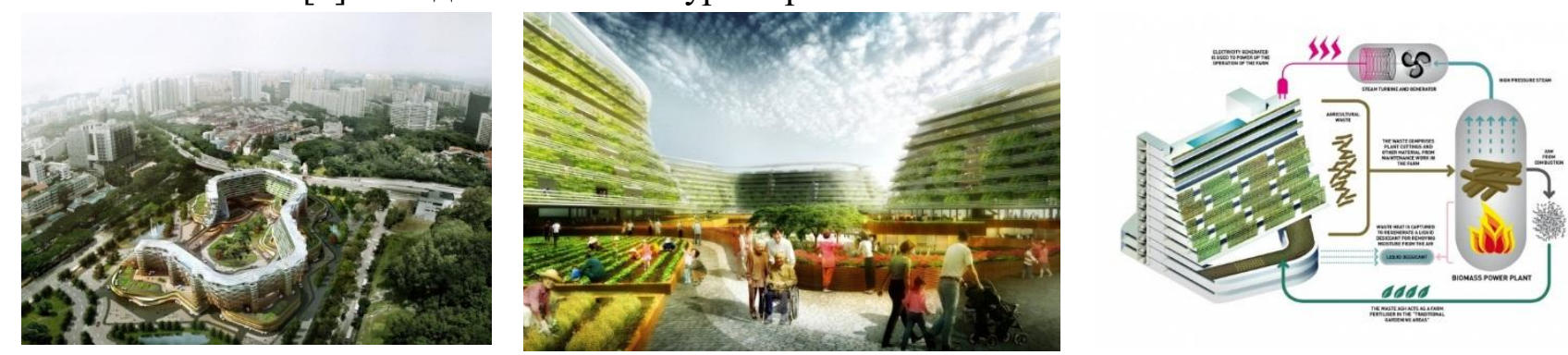

Архитекторы SPARK придумали проект Homefarm - жилой комплекс для пожилых людей со всей необходимой инфраструктурой, рынком, прудами и грядками для выращивания овощей-фруктов. Смелый концептуальный проект, по задумке авторов, поможет решить сразу несколько насущных проблем города-островагосударства Сингапур. Во-первых, он обеспечит растущий контингент пенсионеров доступнымжильем и создаст для них комфортную «среду обитания».Во-вторых, он предлагает решение экологической и продовольственной проблем посредством зеленых террас, крыш и вертикальных огородов, где будут расти свежие овощи и фрукты: их затем можно будет продать на рынке, запланированном на первом этаже, что обеспечит жителей доходом.

Жилой комплекс Homefarm позволит пенсионерам жить, словно на ферме, работать на грядках в свое удовольствие (столько часов в день, сколько им удобно), но при этом оставаться в городской среде, в окружении всей необходимой инфраструктуры, быть частью общества - и близкого по интересам сообщества.

Комплекс представляет собой криволинейный 8-этажный блок с жильем и длинными террасами-садами, который стоит на пяти 3-этажных подиумах, сгруппированных вокруг сада в середине и соединенных между собой переходами. На разных уровнях комплекса предусмотрены сельскохозяйственный центр, рынок, супермаркет натуральных продуктов, центры здоровья и социального обеспечения, 
библиотека, детский сад, торговый зал. За периметр комплекса вынесены четыре водосборных бассейна и въезд в подземный паркинг.

CheerfulCourt находится в Гонконге, Китай.
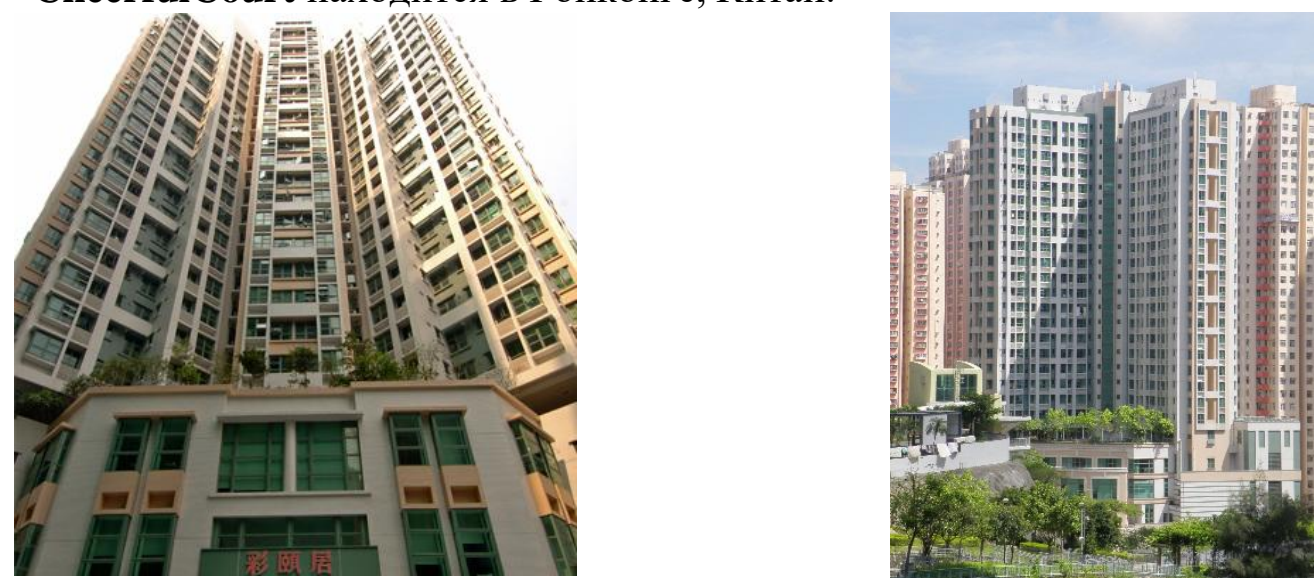

В Гонконге большое внимание уделяется стратегии развития и строительства государственного арендного жилья для пожилых людей. Основной принцип - создать условия для комфортной жизни стареющих людей в домашних условиях «ageinginplace». Основные задачи: интеграция жилья и услуг под одной крышей, поиск оптимального баланса между общественной и частной жизнью, обеспечение безопасности, соответствие разным уровням состояния здоровья. В данном доме 26 этыдей,333 квартиры по 23-35 кв.м.

Этот дом имеет самрфинансирование командой профессионалов из нескольких дисциплинарных групп, состоящих из зарегистрированных медсестер, социальных работников, физиотерапевтов и профессиональных терапевтов, объединенные в группы для оказания комплексных услуг по уходу за жильцами, позволяя пожилым людям жить достойно и мирно.

Архитектура социальных домов должна ориентироваться на потребности пожилых людей, для создания комфортных условий проживания необходимо понять процессы старения в физическом и социальном смысле, поведение пожилых людей и их восприятие окружающей среды в обществе.

Устойчивое развитие городской среды невозможно без комплексного решения таких проблем крупных городов, как нехватка доступного жилья для разных социальных и демографических категорий населения. Пути решения следует искать в направлении поиска новых, более рациональных градостроительных систем с высокой плотностью городской застройки, со смешанным использованием территорий и типологическим разнообразием жилья.

Как планировка пространства и концепция учитывают интересы граждан с проблемами зрения, слуха, равновесия и памяти? Выход на решение рассмотренных проблем требует также и пересмотра профессиональных преставлений о задачах, социальном смысле и самих объектах проектирования, которые сегодня остаются в плену у композиционно-эстетических соображений и часто далеки от реальности. В частности, необходимо развивать формы и методы диалогового проектирования, которое может опираться на средства массового автоматизированного проектирования. 